\title{
EVAPORATIVE WATER LOSS FROM BIRDS: EFFECTS OF ARTIFICIAL RADIATION
}

\author{
BRUCE A. WUNDER \\ Department of Zoology and Entomology, Colorado State University, Fort Collins, CO 80523, and \\ Douglas Lake Biological Station, University of Michigan, Pellston, MI 49769, U.S.A.
}

(Received 11 October 1978)

\begin{abstract}
Metabolism $\left(\dot{V}_{\mathrm{O}_{2}}\right)$ and evaporative water loss $\left(\dot{m}_{\mathrm{ws}}\right)$ were measured in black, male Lark Buntings (Calamospiza melanocorys) at 10,30 and $35^{\circ} \mathrm{C}$ with and without supplemental radiation (simulating sunlight).

2. $\dot{V}_{\mathrm{O}_{2}}$ was reduced by radiation at $10^{\circ} \mathrm{C}$ but not $30^{\circ}$ or $35^{\circ} \mathrm{C}$.

3. $\dot{m}_{\mathrm{uc}}$ was unaffected by radiation at $10^{\circ} \mathrm{C}$, however; it was increased $36 \%$ at $30^{\circ} \mathrm{C}$ and $150 \%$ at $35^{\circ} \mathrm{C}$.

4. I suggest caution should be used in arguing the selective advantages of black pigmentation in environments with incident radiation, for although there may be an energy saving at low ambient temperatures, there is a considerable increase in water loss at high ambient temperatures.
\end{abstract}

\section{INTRODUCTION}

Since the early papers of Gates (1962) and Porter \& Gates (1969) environmental physiologists have frequently dealt with animal thermoregulation as a problem of energy balance (for discussion see: Gates, 1975; Bartholomew, 1977; Campbell, 1977; Robinson et al., 1977). The influence of artificial radiation (simulated sunlight) on metabolism of birds and the role of dark coloration in this interaction has been of special interest (Hamilton \& Heppner, 1967; Lustick, 1969; Heppner, 1970; Lustick et al, 1970; DeJong, 1976). Dark-colored birds absorb more incident radiation than light-colored birds, and experience a greater reduction in metabolic rate when exposed to low ambient temperatures $\left(T_{\mathrm{A}}\right)$ and simultaneous supplemental radiation. Therefore, it has been postulated that there is a selective advantage for dark coloration in birds living in areas with daytime temperature below thermoneutrality and available solar radiation (Cowles, 1967; Hamilton \& Heppner, 1967; Heppner, 1969; Heppner, 1970; Lustick, 1971). However, incident solar radiation and its absorption is simply one parameter of the total energy balance for an animal, and although an increase in solar energy absorption may be advantageous (from an energetic standpoint) at low to moderate $T_{A}$ 's, such absorption would be detrimental at high $T_{\mathrm{A}}$ 's. Under high energy loads the primary means by which most homeotherms maintain energy balance is through latent heat lost by evaporation of water. Frequently, environments which present high solar energy levels also provide little water to animals. Yet there are a number of dark-colored birds which live in warm or hot climates with high incident radiation (e.g. ravens, crows, cowbirds. blackbirds and lark buntings). And, to my knowledge, no one has documented the magnitude of the effect of radiation on evaporative water loss $\left(\dot{m}_{\mathrm{xe}}\right)$ in small, dark birds.

Thus, I undertook this study to investigate the effects of artificial radiation loads on evaporative loss of a dark bird. I chose male lark buntings (Calamospiza melanocorys) as the experimental animal since these small, dark birds normally breed on the hot, arid plains of eastern Colorado.

\section{MATERIALS AND METHODS}

Ten adult male birds were collected on the prairie near Nunn, Weld County, Colorado, in early June of 1975. They were held in the laboratory at $24 \pm 1^{\circ} \mathrm{C}$, on a $12 \mathrm{~L}: 12 \mathrm{D}$ photoperiod for 4 weeks before being tested. Tests were conducted during the birds' daytime hours. Birds were weighed and placed in one-gallon paint cans (painted flat black inside) which served as respirometers. Air flow through the respirometers was maintained at $700 \mathrm{~cm}^{3}$ (min) $^{-1}$ using Brooks E/P flow meters calibrated with a Brooks Vol-U.Meter. Oxygen consumption $\left(\dot{V}_{\mathrm{O}_{2}}\right)$ was monitored with a Beckman model G-2 oxygen analyzer conforming to condition "B" of Hill (1972). Total evaporative water loss $\left(\dot{m}_{w *}\right)$ was measured gravimetrically as in Wunder (1970). Temperature in the respirometer was measured at bird height with a thermocouple shielded from radiation by aluminium foil. The respirometer was placed in a water bath to maintain temperature (within $\pm 0.5^{\circ} \mathrm{C}$ ).

A hole was cut in the respirometer lid and replaced with a piece of glass glued to the lid. This window was kept $1 \mathrm{~cm}$ below the water surface so that when the radiation source (a General Electric infrared lamp, R-40, $250 \mathrm{~W}$ clear-end) was on, the birds received light of wavelengths $400-1400 \mathrm{~nm}$, the upper limit of radiation passing through $1 \mathrm{~cm}$ of water (Ruttner, 1963). After resting values of $\dot{m}_{\mathrm{we}}$ and $\dot{V}_{\mathrm{O}_{2}}$ were determined, the lamp, which was $40 \mathrm{~cm}$ above the respirometer floor, was turned on. This provided a radiation intensity of $390.8 \mathrm{Wm}^{-2}$ at bird height in the can (determined with an Eppley pyranometer). After at least $30 \mathrm{~min}$ of acclimation, when $\dot{V}_{O_{2}}$ held steady with the bird resting for at least $15 \mathrm{~min}, \dot{m}_{\mathrm{wc}}$ and $\dot{V}_{\mathrm{o}_{2}}$ were again measured. If $\dot{V}_{\mathrm{O}_{2}}$ varied during a determination, that $\dot{m}_{\mathrm{we}}$ value was discarded. Birds were also watched periodically to be sure they were not active during the measurements. In several instances after the lamp was turned off, resting levels of $\dot{V}_{\mathrm{O}_{2}}$ and $\dot{m}_{\mathrm{wc}_{\mathrm{c}}}$ were again determined. These levels were always within the range of values determined prior to radiation exposure. Body temperatures $\left(T_{\mathrm{B}}\right)$ of birds were measured with a Schulteis thermometer immediately following radiation exposure measurements. In a separate experiment I determined $T_{B}$ of birds not exposed to radiation but resting in the respirometers.

Birds were tested at three air temperatures: (1) $10^{\circ} \mathrm{C}$ 
which should be relatively unstressful for water loss (Bartholomew, 1972), (2) $30 \mathrm{C}$ which should provide a $T_{\mathrm{A}}$ near or slightly below the thermoneutral zone, and (3) $35^{\circ} \mathrm{C}$ which should begin to stress the birds.

Values reported are means $\pm 1 S . D$. Comparisons among groups were made by unpaired $t$-tests.

\section{RESULTS}

There were no significant differences in body weights, $32.6 \pm 2.3 \mathrm{~g}$ or hody temperatures among the groups during the tests. However, there were statistically significant differences in $\dot{V}_{\mathrm{O}_{2}}$ and $\dot{m}_{\mathrm{wc}}$ as a result of artificial radiation exposure. At $10^{\circ} \mathrm{C}, \dot{V}_{\mathrm{O}_{2}}$ was reduced $20 \%(P<0.05)$ with irradiation and although $\dot{m}_{\text {we }}$ was lower in irradiated birds it was not significantly lower (Table 1). In contrast, at $30^{\circ} \mathrm{C}$ and $35 \mathrm{C}, \dot{V}_{\mathrm{O}}$, was not affected by irradiation, but in both cases $\dot{m}_{\text {uc }}$ increased significantly $(P<0.05)$. At $30^{\circ} \mathrm{C} \dot{m}_{\mathrm{uc}}$ was increased $36^{\circ}{ }_{\circ}^{\circ}$ and at $35^{\circ} \mathrm{C}$ by $150^{\circ}$ \% (Table 1).

Table 1. Effects of artificial radiation on metabolism and evaporative water loss in lark buntings

\begin{tabular}{|c|c|c|c|}
\hline \multirow[b]{2}{*}{ Parameter } & \multicolumn{3}{|c|}{$\begin{array}{c}\text { Ambient temperature } \\
\qquad \mathrm{Cl}\end{array}$} \\
\hline & 10 & 30 & 35 \\
\hline$\dot{V}_{\mathrm{O}_{2}}{ }^{*}$ & $\begin{aligned} & 4.73 \dagger \\
+ & 0.67(9)\end{aligned}$ & $\begin{aligned} & 2.51 \\
+ & 0.28(7)\end{aligned}$ & $\begin{aligned} & 2.35 \\
+ & 0.25(6)\end{aligned}$ \\
\hline$\dot{V}_{\mathrm{O}_{2}}$ Irradiated & $\begin{array}{l}3.77 \\
+0.61(9)\end{array}$ & $\begin{array}{l}2.72 \\
\pm 0.52(7)\end{array}$ & $\begin{array}{l}2.44 \\
+0.30(6)\end{array}$ \\
\hline$\dot{m}_{\mathrm{u}}+$ & $\begin{array}{l}5.94 \\
\pm 1.03(9)\end{array}$ & $\begin{array}{l}7.05 \\
+1.61(7)\end{array}$ & $\begin{array}{l}8.13 \\
+1.33(6)\end{array}$ \\
\hline$\dot{m}_{\mathrm{us}}$ Irradiated & $\begin{array}{l}5.36 \\
\pm 0.91(9)\end{array}$ & $\begin{array}{l}9.62 \\
\pm \\
+2.84(7)\end{array}$ & $\begin{array}{l}20.32 \\
+5.45(6)\end{array}$ \\
\hline
\end{tabular}

${ }^{*} \mathrm{~cm}^{3} \mathrm{O}_{2}(\mathrm{~g} \cdot \mathrm{hr})^{-1}$

+ Values given are means \pm 1 S.D. and sample sizes are in parentheses.

$\ddagger \mathrm{mg} \mathrm{H}_{2} \mathrm{O}(\mathrm{g} \cdot \mathrm{hr})^{-1}$.

\section{DISCUSSION}

These data indicate that although irradiation may allow for an energetic savings in metabolic costs at low $T_{A}$ 's, radiant energy input will substantially increase evaporative water loss at high $T_{A}$ 's. Ecologically, this means either that dark birds must remain in the shade more than similar-sized, light-colored birds at moderate to high $T_{\mathrm{A}}$ with radiation, or they must use more water for evaporative cooling. This is an obvious conclusion of an energy balance approach to understanding homeotherm energetics. However, none of the arguments concerning the adaptive significance of dark coloration has truly considered the potential problems of water balance for birds with high heat loads. In some instances, authors have mentioned a potential water balance problem (Heppner, 1970; Lustick, 1969: Lustick et al., 1970), but have simply concluded that birds could behaviorally avoid the sun and that all birds, regardless of color, have similar radiative characteristics in the shade. In no study was the effect of irradiation on evaporation measured. Given the magnitude of the effect on evaporation. I suggest this would be a strong selective force against dark pigmentation in semi-arid areas. Birds may save energy fover lighter colored counterparts) in the mornings but they should lose activity time and/or water later in the day.

Thus, based on the results of my study, I suggest that investigators studying thermoregulation of homeotherms from an energy balance viewpoint need to be equally cognizant of the effects radiation has on $\dot{m}_{\mathrm{uc}}$ at high $T_{1}$ as well as its effects on metabolism at low $T_{1}$.

Acknowledgements--I thank G. C. Packard. C. R. Tracy. and $\mathbf{G}$. Bakko for comments on an earlier manuscript. This study was supported by an NIH-BRSG grant and a CSL Faculty Research grant.

\section{REFERENCES}

BartHolomew G. A. (1972) The water economy of seedeating birds that survive without drinking. In Proc. $X \mathrm{~V}$ Int. Ornithol. Congr. (Edited by Voous K. H.), pp 237-254. Brill, Leiden.

Bar THOLOMEW G. A. (1977) Body temperature and energy metabolism. In Animal Physiology (Edited by GORDoN M. S.), pp. 364-449. Macmillan, New York.

Campbell G. S. (1977) An Introduction to Entironmental Biophysics. Springer-Verlag. New York.

Cowles R. B. (1967) Black pigmentation: adaptation for concealment or heat conservation. Science 158. 1340-1341.

DeJong A. A. (1976) The influence of simulated solar radiation on the metabolic rate of white-crowned sparrows. Condor 78, 174-179

GATES D. M. (1962) Energy Exchange in the Biosphere. Harper \& Row, New York

Gates D. M. (Ed.) (1975) Perspectives of Biophisical Ec(llogy: Springer-Verlag, New York.

Ifamilton W. J. III \& Heppner F. J. (1967) Radiant solar energy and the function of black homeotherm pigmentation: an hypothesis. Science 155, 196-197.

Hamilton W. J. III \& HeppNer F. J. (1967) Black pigmentation: adaptation for concealment or heat conservation Science 158, 1341.

HEPPNER F. J. (1969) Bird feathers and radiation. Science $164,202$.

HEPPNER F. J. (1970) The metabolic significance of differential absorption of radiant energy by black and whitc birds. Condor 72, 50-59.

HiLl R. W. (1972) Determination of oxygen consumption by use of the paramagnetic oxygen analyzer. $J$. appl. Physiol. 33, 261-263.

Lusrick S. I. (1969) Bird energetics: effects of artificial radiation. Science $\mathbf{1 6 3}, 387-390$.

Lustick S. I. (1971) Plumage color and energetics. Condro 73, $121-122$.

Lustick S. I.. Talbor S. \& Fox E. L. Absorption of radiant energy in redwinged black birds (Agelaim phoeniceus). Condor 72, 471-473.

Porter W. P. \& Gates D. M. (1969) Thermodynamib equilibria of animals with environment. Ecol. Monogr 39, 245-270.

Robinson D. E., Campbell G. S. \& King J. R. (1976) An evaluation of heat exchange in small birds. $J$. Comp. Physiol 105, 153-166.

RUTTNER F. (1963) Fundamentals of Limnology: University of Toronto Press, Toronto.

WUNDER B. A. (1970) Temperature regulation and the effects of water restriction on Merriam's chipmunk. Eutamias merriami. Comp: Biochem. Phisiol. 33, 385-403. 